\title{
Antisymmetry and Word Order in Double Object Constructions in Zarma
}

\author{
Waheed Ayisa Jayeola (Ile-Ife)
}

\begin{abstract}
Double Object Construction in Zarma sometimes allows alternations in the order of its internal arguments and the order in some cases may also be fixed. This tendency does not make predictions about a canonical order for the occurrence of Theme and Recipient objects within the VP simple. The same condition applies to monotransitive structures which vary between a complement-head and a head-complement order. It is the aim of this paper to present and analyse the most salient features of the kind of variations found in Zarma word order, particularly the ones associated with the verb that encodes three-participant events. The paper adopts the minimalist program proposed by Chomsky and is complemented with the Antisymmetry Hypothesis proposed by Kayne (1994). The study shows that the language has a uniform linear order where the recipient canonically precedes the theme on the basis of animacy factor. This is particularly common with the pronoun as the recipient in double object structures. Employing different diagnostics, the paper concludes that the recipient only follows the theme when the theme is associated with a more prominent discourse status. It is also argued that asymmetric C-command always occurs between the theme and the recipient. It implies that the language symmetry is altered by movement to designated positions for the purpose of feature checking.
\end{abstract}

\section{Introduction}

Double object construction is a typical three-argument structure while a monotransitive construction is a two-argument structure. At the surface structure level, the position of the verb relative to its argument(s) in Zarma is not fixed in both monotransitive and double object constructions. Thus, it is not so simple to state the basic/unmarked word order in the language. Unfortunately, information about Double Object Constructions is uncommon in the language. Paying attention to this construction type will bring out its formal properties.

Zarma is a language that belongs to the Songhai group of the Nilo-Saharan family, spoken mainly in Niger Republic and some border towns in the north-western states of Sokoto, Kebbi and Zamfara in Nigeria. Like many other African languages, Zarma is a register tone language with two phonemic level tones - high and low. The language displays diverse word order strategies and its word formation is by affixes, mostly suffixes. In its genitive constructions, the possessor occurs before the possessed. It does not mark gender and it spots postposition at the superficial level. 
It is not strange to argue that many languages have considerable word order flexibility and in some languages, it is not easy to establish a dominant order. Nevertheless, it is still a fact that languages are not as inconsistent with respect to word order. Of interest to this study is the structure of the VP in Zarma which is without a fixed order i.e. complement-head and headcomplement are attested. Certainly, it is unsystematic to assume that both VO and OV apply to the same VP. It is also not likely that recipient-theme and theme-recipient orders in double object constructions are alternative choices in the language. Our assumption here takes into consideration the likely specific or formal properties of monotransitive and double object constructions in Zarma. In the light of the formulated hypothesis, this paper will focus on the relationship between linear orders of constituents (internal arguments) vis-à-vis the role of animacy, nominal versus pronominal status, definiteness and emphasis.

In section 2, a synopsis of the theoretical framework adopted is given. Section 3 presents a detailed discussion of monotransitive constructions in Zarma. Section 4.0 deals with word order in double object constructions - simple and imperative. Explanations on the peculiar behaviour of personal pronouns as recipient arguments in double object constructions are given in section 4.2. Sections 4.3 and 4.4 provide theoretical accounts of asymmetric c-command and case respectively. Section 5 is a conclusion.

\section{Theoretical Framework}

The theoretical framework adopted in this paper is the minimalist program (MP henceforth) proposed in Chomsky $(1993,1995,2000$, etc.) complemented with the Antisymmetry Hypothesis proposed by Kayne (1994). MP, unlike Principles and Parameters Theory, uses smaller number of assumptions to capture the syntax of natural language. The major operation used in MP to build syntactic structures is merge- a mathematical operation that combines selected lexical items from the set in a numeration subject to the binary principle. The relevance of the LCA (Linear Correspondence Axiom) which is a product of the Antisymmetry Theory is at this point brought to bear because merge is said to generate unordered structures while the LCA gets the structures ordered. Of importance to our analysis is the Split VP-Hypothesis. The Split VP otherwise known as VP-Shells or Light Verb account is a hypothesis of MP which assumes that VPs have a complex structure. This comprises an inner VP and an outer vP shell such that agent arguments originate within the outer vP shell while other arguments such as theme, patient, experiencer, etc. originate within the inner core VP shell. The introduction of the SplitVP Hypothesis is designed to solve the puzzles created in the analysis of constructions involving two internal arguments.

\section{$3 \quad$ Object Verb Order in Mono-argument Structures}

The argument we would like to pursue in this paper, following Kayne (1994), is that Zarma is an SVO language and that the SOV order found in it is derived. We will employ three different diagnostics to test the possible reasons for the alternations. The diagnostics are: auxiliated OV, OV for definite marking and OV for expressing emphasis. Each of these accounts will be discussed in turn. 


\subsection{Auxiliated Object Verb Order}

Zarma is not a FINITE OV language because it does not have the feature (S O V-Tense) like Izon (cf. Manfredi 1997: 86). However, as the examples in (1) show, the language at first sight appears to display AUXILIATED OV because we find structures such as (S Aux O V).

Let us consider the examples below.

(1)

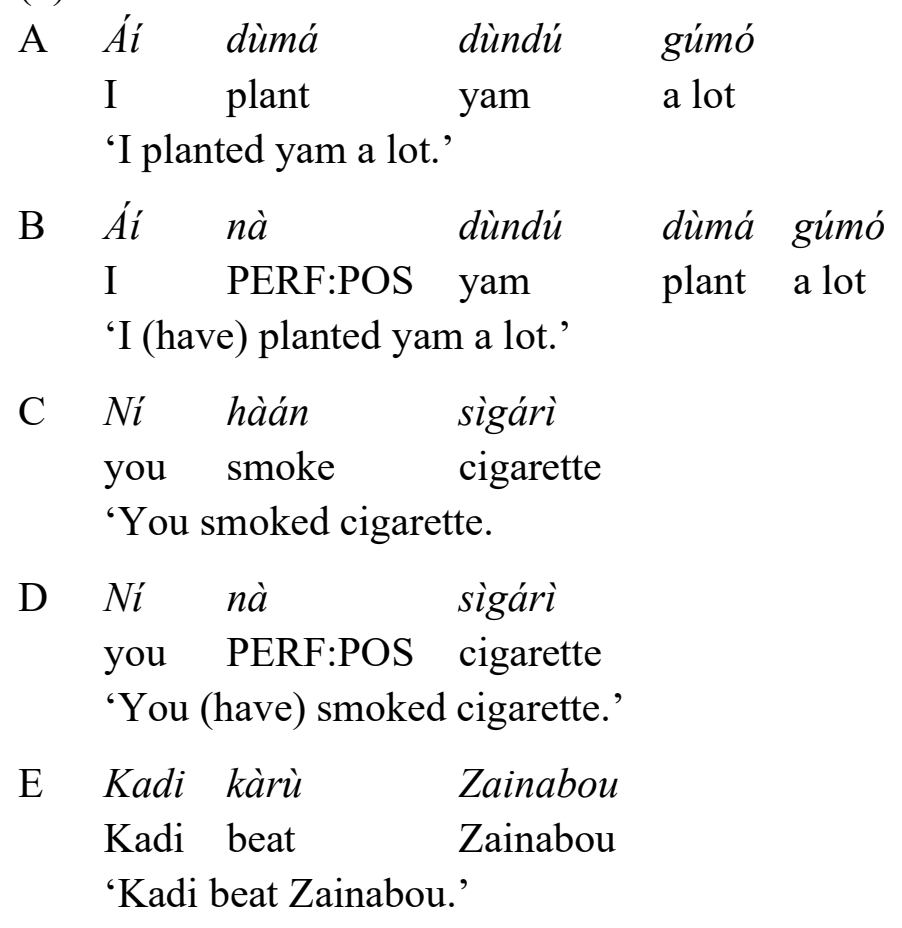

In (1a, c and e), the VP is head initial and it is the form we propose as the unmarked or normal order. However, the counterparts in ( $1 \mathrm{~b}$ and $\mathrm{d}$ ) have head final VP and we speculate that they are the deviant or derived order. A likely reason for the OV order in examples ( $1 \mathrm{~b}$ and $\mathrm{d})$ is morpho-syntactic in nature. It is assumed to draw on the presence of the morpheme nà, glossed as perfective (positive) marker 'have', which may not be so realized always. This claim is suggested by the glosses provided for ( $1 \mathrm{~b}$ and $\mathrm{d})$. It may be the case that there is something in the particle that makes the object to raise from a post-verbal position to a pre-verbal position. One piece of evidence that appears to favour this claim comes from the example below:

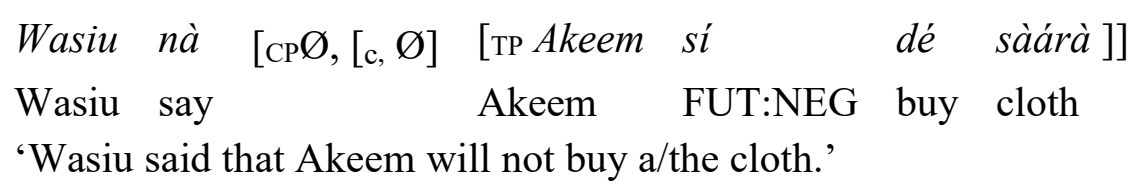

As shown in (2), nà glossed as 'say' is a complement-taking verb that subcategorises for a complement clause whose head is not morphologically filled or has a head that is understood but unpronounced. Given the configuration in (2), it may be logical to propose that nà actually started as a verb in the language. However, its use as an aspect in examples ( $1 \mathrm{~b}$ and d) may be the result of generational or historical stages of the language development which reduces it to aspect. In the lexicon, it is possible to have two identical words with different meaning/function; therefore it is possible to have two or more $n a$ in this language. If our corpus in (1 and 2) is 
taken for the whole fact of Zarma, then our analysis of nà as the element that triggers object shift and forces the object out of the verb C-command domain appears to be in order. It essentially supports the assumption that every VP is a proposition that requires a subject ${ }^{1}$. This type of account is not an isolated case since similar situation occurs in Nupe (cf. Madugu 1986, Cormack/Smith 1994, Kandybowicz/Baker 2003), Mandekan and Gbe (cf. Heine 1980), Kru (cf. Marchese 1981); Vata, Gbadi, and Kpele (cf. Koopman 1984). Manfredi (1997) refers to this as a case of auxiliated OV. Using the evidence of perfectivity, Manfredi, following Heine (1980) and Marchese (1981) makes two possible analyses available:

$$
\left.\begin{array}{llllll}
\text { A } & \text { S } & \text { Aux } & \text { O } & {[\mathrm{V}} & <\mathrm{O}>
\end{array}\right]
$$

According to Heine, (3a) corresponds to object shift or preposing, a term understood as object argument raising in the minimalist tradition. To Marchese, (b) is linked to $\mathrm{V}$-movement or verb postposing otherwise referred to as $\mathrm{V}$ lowering in minimalism. Apart from being strange to minimalism, it is improper to assume that perfectivity triggers verb-postposing as in (3b). This is due to the fact that Zarma does not generally favour rightward movement i.e. within its DP (cf. Jayeola 2016). It is therefore not likely that the VP would take exceptions. While we jettison $(3 b)$, it is our assumption that (3a) is true for the language.

One advantage of sticking to (3a) is that it shows the defect in Vicente's (2004) claim that on top of OV order, manner adverbs are obligatorily post verbal in Zarma. It is not out of place to say that manner adverbs modify the head of the predicate phrase; they do not contribute significantly to the generation of OV order in Zarma. According to Vincente (2004: 85), examples of the type in (4a-b) are ungrammatical because the adverb gúmó 'a lot' appears in pre-verbal positions. However, example (4c) is correct because an adverb such as gúmó must appear in post-verbal position.

$\begin{array}{llllll}\text { A } & \text { *Zànkàà } & \text { nà } & \text { gúmó } & \text { hánsò } & \text { kàrù } \\ & \text { child:DEF } & \text { PERF:POS } & \text { a lot } & \text { dog:DEF } & \text { beat } \\ \text { B } & \text { *Zànkàà } & n a ̀ & \text { hánsò } & \text { gúmó } & \text { kàrù } \\ & \text { child:DEF } & \text { PERF:POS } & \text { dog:DEF } & \text { a lot } & \text { beat }\end{array}$

$\begin{array}{llll}\text { C Zànkàà nà } & \text { hánsò } & \text { kàrù } & \text { gúmó } \\ \text { child:DEF } & \text { PERF:POS } & \text { dog:DEF beat } & \text { a lot } \\ \text { 'The child beat/has beaten the dog a lot.' } & \end{array}$

\footnotetext{
1 The speculation in this direction is confirmed by some expressions in the language where in serial verb constructions and subordinate clauses, $n a$ appears to function as a meaning bearing verb. Consider the example below:

Kadi nàngà dé sàárà Sheu sè

Kadi say 3 sg buy cloth Sheu $P$

'Kadi said that she bought a/the cloth for Sheu'
} 
A plausible assumption along this line is that, in addition to serving as the direct object of the verb kàrù, hánsò also seems to function like a complement to nà. This probably explains why gúmó 'a lot', an adjunct, cannot intervene between the perfective marker nà, and hánsò, 'the dog' in (4a) and between hánsò and the verb kàrù in (4b). It is evident from this analysis that adverbs are mobile but are not unconstrained. This may be the reason why the appearance of gúmó 'a lot' before the perfective marker in (4d), and its positioning after the verb in (4c) does not make the sentence or derivation to crash.

(4)

D Quadri gúmó nà $\quad$ mòó j̀wá
Quadri a lot PERF:POS rice eat
'Quadri ate/has eaten rice a lot.'

The behaviour of gúmó 'a lot' in Zarma seems to justify the treatment of adverbs as an adjunct that freely and optionally adjoins to any category. This account is in line with Kayne's (1994) Antisymmetry of syntax which permits a wider range of categories and the introduction of new functional categories as the hosts of movement.

However, the motivation for object shift in Zarma in relation to perfectivity seems to crumble if we consider other examples. It is possible to also have head-final VP in constructions with imperfective elements. This is the case with the following expressions.

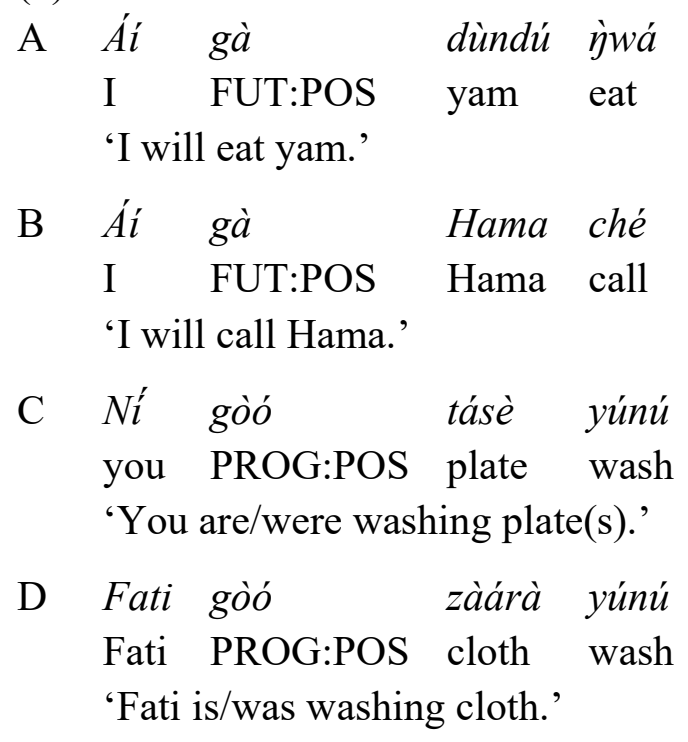

All of the examples in (5) are similar to what we witness of perfective OV in (1). In agreement with the account so far given in this article; it may not be out of order to tentatively consider the examples in (5) as future cum progressive OV constructions. This account finds support in Manfredi (1997: 87) who asserts that "The specific trigger of object shift varies: in Gbè, it is a progressive Aux (but not always) or a closed set of matrix control verbs; in Standard İgbò and Yorùbá, only control verbs trigger OV; nonstandard Ìgbò and Yorùbá varieties have future and perfective OV constructions respectively, but not OV progressives." 
Similar occurrence of what is described above is found in a language like Irish. According to Carnie (2007: 379), in literary Irish, the object follows the main verb in the progressive aspect (6b) and takes the genitive case. In the recent perfective (6a), object precedes the main verb (and the particle $a^{L}$ ), and takes the accusative case.

(6)

$\begin{array}{lllll}\text { A Tá Seán tar eis an } & \text { abairt } & a^{L} \\ \text { be:PRES John PERF the } & \text { sentence } & \text { TRAN } \\ \text { 'John has just written the sentence.' } & \\ \text { B Tá Seán ag scriobh } & \text { na } & \text { habairte } \\ \text { be:PRES John PROG write the } & \text { sentence } \\ \text { 'John is writing the sentence.' } & & \end{array}$

Contrary to what we have observed and analysed, the data in (7) appear to suggest that we may have to look beyond grammaticalization as the evidence for S-Aux-O-V X in Zarma because even where there are auxiliary particles, it is still possible for the VP to be head-initial. We notice that despite the presence of gà and gòo which we have interpreted as Future and Progressive markers (positive) in ( $7 \mathrm{a}$ and $\mathrm{b}$ ) respectively, the verbs in those examples still take their objects to the right. This phenomenon may relate to the exemption which Manfredi (1997) reports in the quotation above.

(7)
A Aí gà ché Hama FUT
I FUT:POS call Hama
'I will call Hama.'
B Írì gòó yúnú tásè PROG
we PROG:POS wash plate
'We are/were washing plate(s).'

Negative constructions as we have in (8) and (9) are also intriguing.

(8)
A Aí sí Hama ché
I FUT:NEG Hama call
'I will not call Hama.'
B Ái si ché Hama
I FUT:NEG call Hama
'I will not call Hama

(9)
$\begin{array}{cllll}\text { A } & A i ́ & \text { sígà } & \grave{y} w a ́ & \text { mòó } \\ & \text { I } & \text { PROG:NEG } & \text { eat } & \text { rice }\end{array}$
'I am/was not eating rice.' 


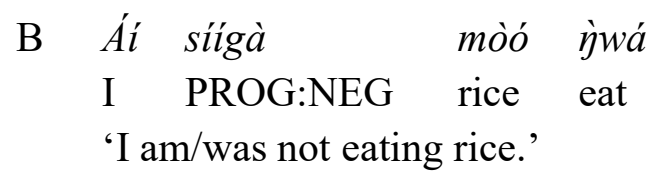

We observe from our glosses of the data in (8 and 9) that tense/aspect and negation are semantically fused in one single morph. Similar to the situation in (7), an unconstrained order in the position of object, relative to the verb is tolerated. This seems to be a pointer to the weakness of an auxiliated OV account; it is slippery and not intuitively satisfying.

\subsection{OV Order and Definite Marking}

Another viable motivation for OV generation in Zarma seems to come from definite versus indefinite marking on object DPs.

\begin{tabular}{|c|c|c|}
\hline A & $\begin{array}{l}I \quad \text { háwú } \\
\text { they goat:DEF } \\
\text { 'They beat the go }\end{array}$ & $\begin{array}{l}\text { kàrù } \\
\text { beat } \\
\text { at.' }\end{array}$ \\
\hline 3 & 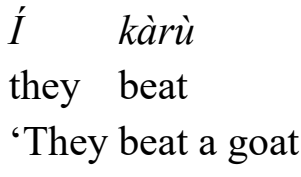 & $\begin{array}{l}\text { háwú } \\
\text { goat:INDEF }\end{array}$ \\
\hline $\mathrm{C}$ & 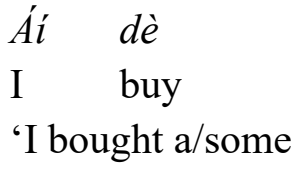 & $\begin{array}{l}\text { kòròfó } \\
\text { rope:INDEF } \\
\text { ope(s).' }\end{array}$ \\
\hline & $\begin{array}{l}\text { kòròfó } \\
\text { rope:DEF }\end{array}$ & $\begin{array}{l}d \grave{e} \\
\text { buy }\end{array}$ \\
\hline
\end{tabular}

Our translations of the constructions in (10) show that háwú 'goat' and kòròfó 'rope' are bare nouns which may be interpreted as either indefinite or definite without any corresponding change in their morphological forms. However, we observe syntactic variations in the order of the object DPs. This fact bears direct relationship on reports by Cheng/Sybesma (1999), and Aboh (2004a, b) that Sinitic and most Niger-Congo languages do not have definiteness articles of the Indo-European type, but encode definiteness by other syntactic devices that are arguably not expressions of D i.e. pre- versus post-verbal position. By implication, it means that Zarma can encode definiteness ${ }^{2}$ by a syntactic device of pre- versus post-verbal position. However, this report can hardly be generalized for some languages. In Zarma for instance, it merely indicates that definiteness is a condition under which the object can precede the verb to yield OV order. This fact becomes clear in situations where a DP that morphologically inflects for definiteness follows the verb. This is the case with the examples below.

\footnotetext{
2 Zarma, as suggested by the data in (10), has the tendency to encode definiteness by syntactic devices of preversus post-verbal position. It is not all about the language. There are a number of nouns in the language that are morphologically distinctive i.e. they inflect for definiteness.
} 
$(11)$

\begin{tabular}{|c|c|c|c|}
\hline A & $\begin{array}{ll}A^{\prime} i & n a ̀ \\
\text { I } & \text { PERF:POS }\end{array}$ & $\begin{array}{l}\text { wi } \\
\text { kill }\end{array}$ & $\begin{array}{l}\text { fèjò } \\
\text { sheep:DEF }\end{array}$ \\
\hline & 'I (have) killed $t$ & le sheep.' & \\
\hline & Ái sómbú & nòòró & \\
\hline & I take & money:DEF & \\
\hline & 'I took the mone & & \\
\hline
\end{tabular}

The definite feature of the objects in (11) predicts that the evidence for definiteness as a condition or trigger for OV order is not strong enough in the language.

Given the first two diagnostics, the alternations we have found in object positions differ in their specifics but they have not provided a unified account or a principled solution to the alternations. To analyse the situation as a process of stylistic re-ordering ${ }^{3}$ where the base generated VO order optionally gets altered at the PF level to produce OV order may not be intuitively satisfying if the example sentences in (10) are rigidly considered. Despite the precarious nature of the two diagnostics so far examined; the position of this paper is that Zarma word order is constrained.

\subsection{Emphasis as a Trigger for OV Order}

There appears to be a salient feature of Zarma that our analyses, based on our glosses of the data, have not assisted us to uncover. It looks like there is a difference in meaning beyond definiteness between post-verbal and pre-verbal positions of object within Zarma clause. Consider the examples below:

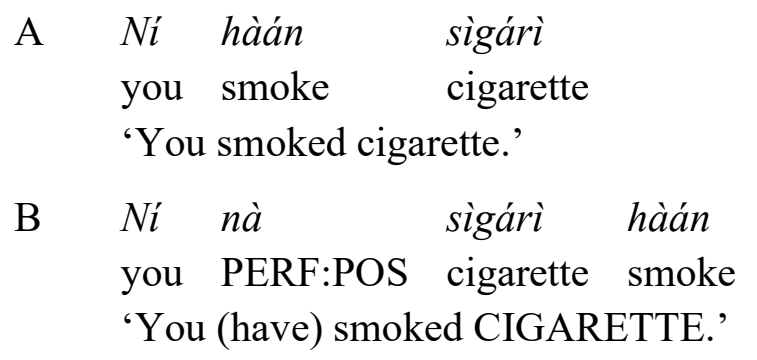

The expression in (12a) is an ordinary declarative statement which affirms the action expressed by the verb and as performed by the agent $n i$ ' 'you'. There is no contrast of any sort between the subject and the object. However, when the object precedes the verb in (b) there is a difference in meaning. The OV order indicates that the object is essentially the relevant item to the exclusion of other possible candidates. In other words, the object in (b) is emphasized and not the subject or any other element within the sentence. The same relationship exists between the following set of data.

\footnotetext{
${ }^{3}$ The corpus of data used in this study does not support a description of word order phenomena in terms of pragmatic criteria which focus on the relationship between order and speaker-hearer interpretation as well as the means through which speakers can orient the listener's interpretation.
} 
(13)

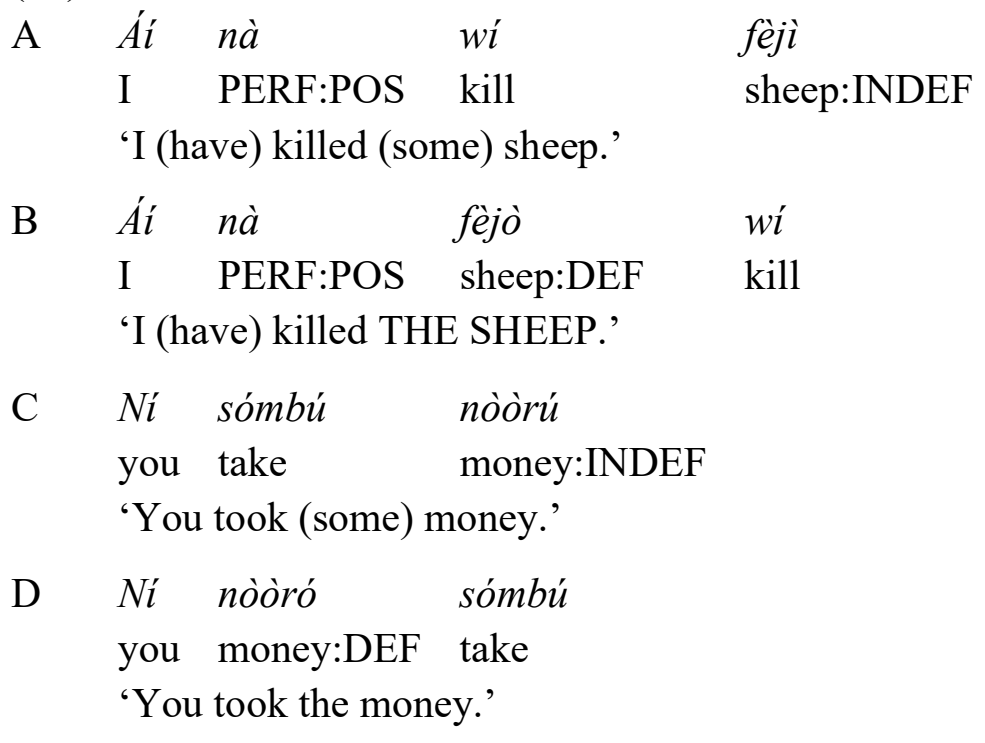

(13a, c) are neutral sentences where no element receives any form of prominence. It is not the same with (b, d) because the objects féjó 'the sheep' and nò̀ró 'the money' in addition to being definite morphologically, their pre-verbal position is indicative of emphasis. This account clearly shows the difference in meaning between examples (11) and (13b, d). Semantically speaking, the difference between the terms definiteness and emphasis is imperceptible. And in the minimum, our example sentences in (10-13) seem to show that the two meanings could be fused. One way of making OV order exclusive to emphasis is to say that a pre-verbal object position is marked for emphasis because we also find VO definite object. We adopt this position and indicate such in the following examples.

(14)

\begin{tabular}{|c|c|c|}
\hline A & $\begin{array}{ll}A \grave{i} & g \grave{a} \\
\text { I } & \text { FUT:POS }\end{array}$ & $\begin{array}{l}\text { dùndú } \\
\text { yam+EMPH }\end{array}$ \\
\hline & 'I will eat YAM.' & \\
\hline $\mathrm{B}$ & $\begin{array}{l}A \grave{A} \quad n a ̀ \\
\text { I PERF:POS } \\
\text { 'I ate YAM.' }\end{array}$ & $\begin{array}{l}\text { dùndú } \\
\text { yam+EMPH }\end{array}$ \\
\hline $\mathrm{C}$ & $\begin{array}{ll}A i ́ & \text { sígà } \\
\text { I } & \text { PROG:NEG }\end{array}$ & $\begin{array}{l}\text { mòó } \\
\text { rice+EMPH }\end{array}$ \\
\hline
\end{tabular}

The interpretations of the above sentence show that pre-verbal objects are well determined and crucial referents. This account does not exclude negative expression as the example in (c) suggests.

\subsection{Analyzing the OV Order in Monotransitive Constructions}

Based on the pervasive nature of a semantic account which has helped to harmonize the diagnostics, we assume that the alternations revolve around emphasis/definiteness rather than being 
aspectually driven. The implication of this analysis is that Zarma is configurationally SVO but $\mathrm{SOV}$ is evoked whenever the object receives emphasis from the discourse.

According to Kayne (1994), SVO is the universal order; any case of deviations must be seen as the consequence of movement. Thus, a proposal that object raising is used to encode emphasis/definiteness by a syntactic device of pre- versus post-verbal position appears to be intuitively satisfying. In this regard, the object raises to a functional specifier position for a semantic reason. This proposal is captured in the schema below.

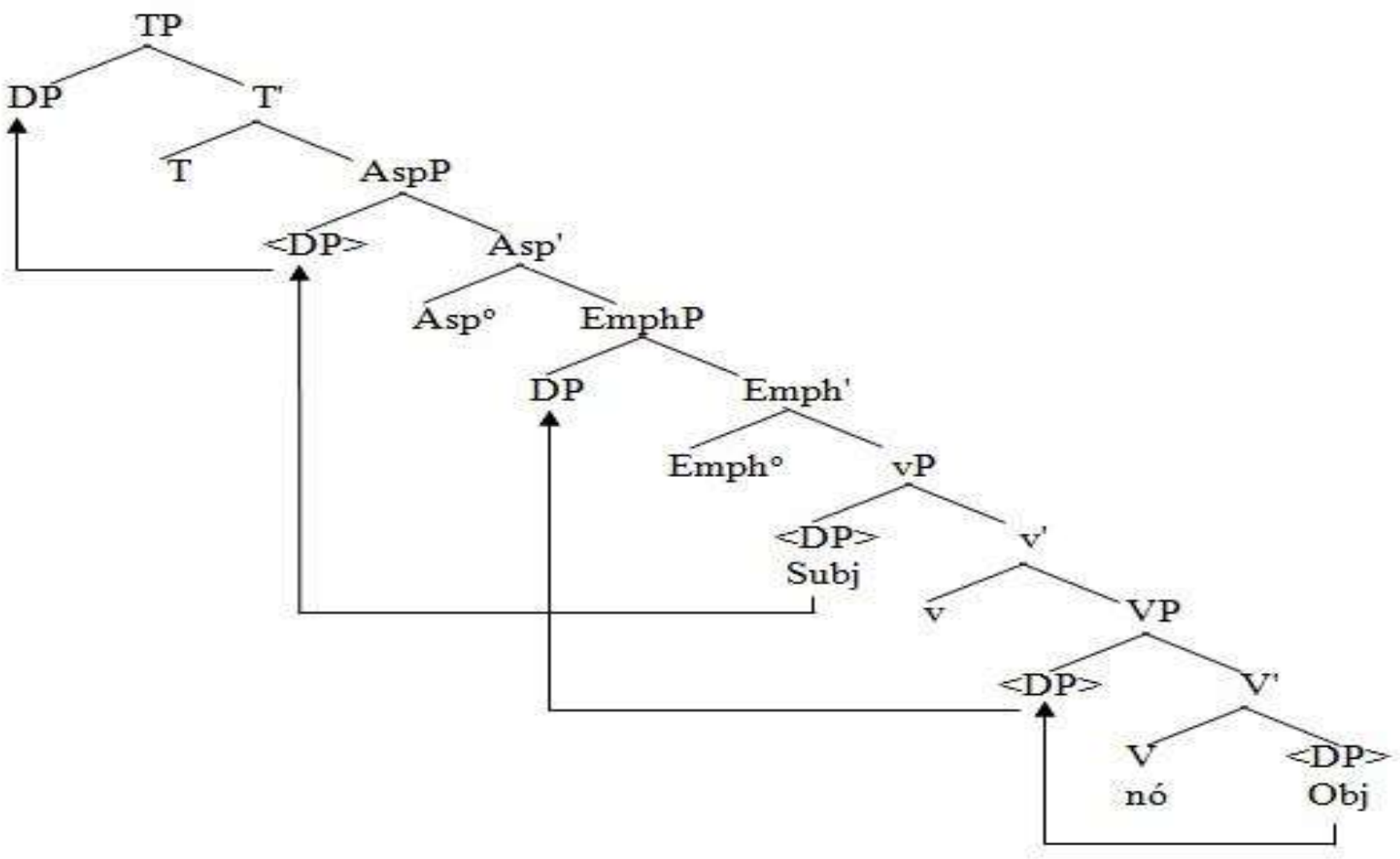

(15) Tree diagram showing that the object DP follows the Verb in Zarma

The configuration in (15) is the output of operation merge which shows that the object DP follows the Verb at the underlying level but it does not represent the correct linear order for sentences of the type in (1b, d, 10a, $d$ and 14). To derive the correct linear order; we assume, following the minimalist account that structures are assembled by applications of the operations Merge and Move which in principle do not set limit for the number of Specifiers a given category can have. Thus, on the assumption that object shift is caused by the need to place emphasis on it, we instigate an Emphatic functional category that has a null/covert head ${ }^{4}$. The specifier position of the special functional category allows the moved object i.e. internal argument to check its emphatic feature under a Spec-head relation moving cyclically through the spec-lower VP. The phrase marker shows that the light verb or upper verbal shell is morphologically empty; it is due to the absence of any trigger for the movement of the lower/inner VP. Also, the DP subject (external argument) originates at the specifier position of the upper $\mathrm{vP}$ shell where it is assigned a $\theta$-role, depending on what constitutes the vP (the verb and its internal argument), raises or moves to the Spec-TP to check its nominative case. The movement of the object and

\footnotetext{
4 This account is similar to the situation in Tunen (Mous 1997). The difference between Tunen and Zarma is that while emphatic head is null or covert in Zarma it is overt in Tunen.
} 
the subject replicates the unified spec-head case checking relationship, Hornstein et al $(2005)^{5}$. What we have presented in (15) captures Kayne's (1994) proposal that the differences exhibited by the head parameter are not due to underlying structural differences but rather to differences in movement.

\section{$4 \quad$ Word Order in Simple Double Object Constructions}

In section (3), we explain different conditions or diagnostics for object shift and adopt the proposal that the alternation seems to be linked to emphasis. The focus of this section however is to look at Double Object Constructions (DOCs) and analyse the asymmetry in the order of the recipient and the theme objects relative to the verb. It is equally the focus of this section to provide explanations on how case and theta roles are assigned to each of them. The DOCs we intend to investigate here do not correspond to verbs taking one nominal and one prepositional or postpositional complement, but those in which verbs take two DP complements- indirect object (recipient) plus direct object (theme), (cf. Marantz 1984, Borsley 1991). The situation looks like the one in which the recipient is treated exactly the same as the patient of a typical transitive verb.

What is intriguing about Zarma is that it is not so simple to state any canonical or unmarked order for the theme and the recipient. This is unlike Batonu where the order [IO-DO-V] is sacrosanct and cannot be altered under any guise, Sanusi (2001: 140). Kandybowicz and Baker (2003: 124) also give similar report on Nupe, where the goal DP (recipient) must precede the main verb, and the theme DP must follow it. The reverse order is not possible when the aspect is perfective in $\mathrm{DOC}^{6}$. The different orders tolerated in Zarma DOCs are presented in (16 and 17) below:

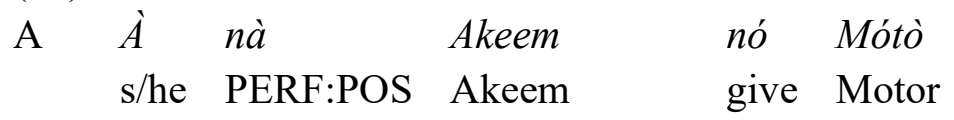

'S/he gave/has given Akeem a motor car.'

$\mathrm{B}$ À nà mótò nó Akeem

$\mathrm{s} /$ he PERF:POS motor+EMPH give Akeem

'S/he gave/has given Akeem a MOTOR CAR.'

(17)

A
Aí sì
Zainabou
nó nòòrú
I FUT:NEG Zainabou
give money:INDEF
'I will not give Zainabu money.'

$\begin{array}{cllll}\text { B } & A i ́ & s i ̀ & \text { nòrú } & \text { nó Zainabou } \\ & \text { I } & \text { FUT:NEG } & \text { money:INDEF+EMPH } & \text { nó Zainabou }\end{array}$

\footnotetext{
5 See Hornstein et al (2005: 116) for an argument for a unified Spec-Head case checking relationship.

6 This report from Kandybowicz/Baker (2003: 124) seems to lend credence to our account on the relevance of aspect in the generation of OV order in Zarma but it does not stand out to be pervasive.
} 
'I will not give Zainabou MONEY.'

The manner of word order found in the DOCs in (16 and 17) indicates that any of the two DP objects, recipient/theme can precede or follow the verb that governs them, even in negative expressions $(17 \mathrm{a}, \mathrm{b})$. The traditional notions of "Indirect object" or "Dative" are difficult to apply here because nouns do not have case variations. Also, the recipient does not stand in a more or less specialized dative case, (cf. Creissels et al 2008: 100). However, the order is relatively fixed when the structure is realized as a postpositional ditransitive ${ }^{7}$. This is shown in the examples below.

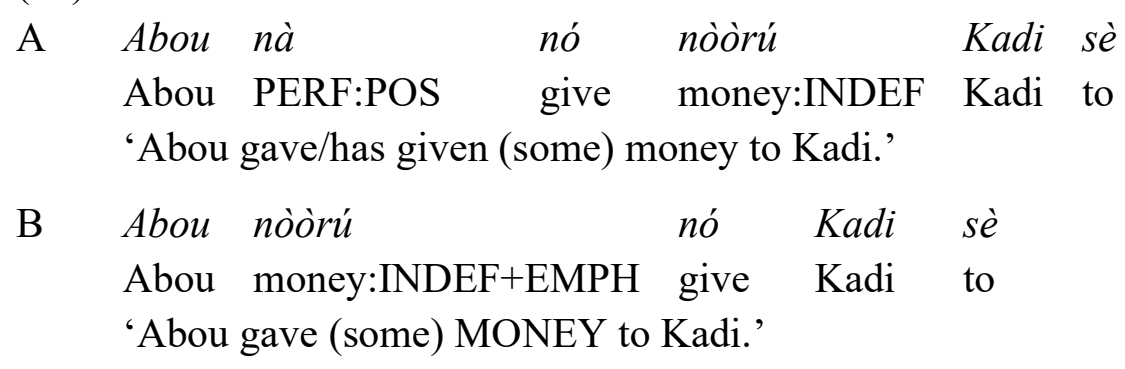

In (18), the position of the theme is free relative to that of the recipient which stands in complement position to the head se 'to'. It is the case that the theme is emphasized in (16b,17b and $18 \mathrm{~b}$ ) forcing it to raise to a preverbal position. It should be noted that the double object construction that we focus on in this paper is not the same as pre- or post- positional dative construction.

Given their relatedness however, it is plausible to recognize the alternations in (16 and 17) and (18) as an instance of movement. Nevertheless, it looks like double object construction and postpositional dative structure have different thematic properties in Zarma and that they have distinct underlying structures. One noticeable constraint in the order of object DPs in DOCs is that the two objects can neither occur to the left of the verb that governs them nor to its right. This is why the following sentences do not converge.

$\begin{array}{llllll}\text { A } & \text { *Zinabou } & \text { mótò } & \text { Akeem } & \text { nó } & \\ & \text { Zainabou } & \text { motor car } & \text { Akeem } & \text { give } & \\ \mathrm{B} & * \grave{A} & \text { nà } & \begin{array}{l}\text { bónkàrèè } \\ \text { cloth }\end{array} & \begin{array}{l}\text { Juwerah } \\ \text { Juwerah }\end{array} & \text { nó } \\ & \mathrm{s} / \text { he } & \text { PERF:POS } & \\ \mathrm{C} & * \text { Zainabou } & \text { nó } & \text { Akeem } & \text { zààrà } & \\ & \text { Zainabou } & \text { give } & \text { Akeem } & \text { cloth } & \\ \mathrm{D} & \text { *Zainabou } & \text { nà } & \text { nó } & \text { zàárà } & \text { Akeem } \\ & \text { Zainabou } & \text { PERF:POS } & \text { give } & \text { cloth } & \text { Akeem }\end{array}$

Following from our discussions of the mono-transitive constructions in section(3), it is still safe, since one of the objects must come after the verb, to say that the VP in Zarma is canonically

\footnotetext{
${ }^{7}$ Zarma spots postposition in its superficial syntax, however, Jayeola (2016) following Hornstein et al (2005) has analysed the phenomenon as a case of movement evoked by feature checking.
} 
head initial. In which case, one of the objects must move for the purpose of checking its feature (emphasis). It is assumed that the ungrammaticality of the sentences in (19) is borne out of the inability of the ditransitive verb to form complex predicate thereby making the invocation of the notion of Abstract Noun Incorporation impossible.

\subsection{Imperative and Double Object Constructions}

The alternations in the order of the internal arguments of a double object construction witnessed in section (4.0) are not maintained in its imperative counterparts (positive). It appears the position of each of the recipient and theme objects is fairly slightly fixed; any attempt to reorder them, which is permissible in simple DOC, will result in the generation of ungrammatical/unacceptable sentences. This is shown in (20).

\begin{tabular}{|c|c|c|c|}
\hline A & $\begin{array}{l}\text { Nó } \\
\text { give }\end{array}$ & $\begin{array}{l}\text { Zainabou } \\
\text { Zainabou }\end{array}$ & $\begin{array}{l}\text { nòòrú } \\
\text { money:INDEF }\end{array}$ \\
\hline & 'give & Zainabou (som & e) money.' \\
\hline B & *nó & nò̀̀rú & Zainabou \\
\hline & give & money & Zainabou \\
\hline $\mathrm{C}$ & $N o ́$ & nòòrú & Zainabou \\
\hline & & money:INDEF & Zainabou \\
\hline
\end{tabular}

Example (20) indicates that imperative construction in its positive form only allows the understood recipient object to follow the verb directly while the theme object comes immediately after. (20b) is ill-formed although same as with (a) where the two objects are on the same side of the verb. It is probably the case that the recipient Zainabou is human and is favoured to precede the theme nò̀ru' 'money' which is inanimate. To repair the structure in (b), the recipient needs to be introduced by a postposition. This explains the grammaticality of its counterpart in (20c). Some amount of interpretive correlations exists between (20a and c) though they are structurally different.

However, this order is not preserved when the example in (20a) is negated. Consider the expressions in (21).

$\begin{array}{lllll}\text { A } & \begin{array}{l}\text { Màsi } \\ \text { IMP:NEG }\end{array} & \text { Zainabou } & \text { nó } & \text { nò̀rú } \\ \text { 'don't give Zainabou money.' } & \text { give } & \text { money:INDEF } \\ & \text { Bàsí } & \text { nòòrú } & \text { nó } & \text { Zainabou } \\ \text { B } & \begin{array}{l}\text { IMP:NEG } \\ \text { 'don't give Zainabou MONEY.' }\end{array} & & \end{array}$

Now, we have seen the difference in the order of object DPs in $(20,21)$. One plausible explanation we can provide for the alternations is that, in (20), the two internal arguments of the verb nó 'give' can only follow the verb and the recipient must immediately follow the verb because 
it is human and considered definite. This account seems to suggest that the canonical order in Zarma is likely to be recipient before theme when the recipient is not flagged by a postposition (16a, 17a and 20a). This fact conforms to the order in (21a). The order found in (21b) is understood as the effect of movement triggered by its discourse status i.e. the need for the theme which is both inanimate and indefinite to be marked for emphasis. It means that there is semantic difference between the alternating patterns. This account finds support in the structures below where 'money' nò̀rú morphologically inflects for definiteness.

$\begin{array}{lllll}\text { A } & \text { Màsí } & \text { Zainabou } & \text { nó } & \text { nòòó } \\ & \text { IMP:NEG } & \text { Zainabou+EMPH } & \text { give } & \text { money:DEF } \\ & \text { 'don't give ZAINABOU the money.' } & \\ \text { B } & \text { Màsí } & \text { nòòró } & \text { nó } & \text { Zainabou } \\ & \text { IMP:NEG } & \text { money:DEF+EMPH } & \text { give } & \text { Zainabou } \\ & \text { 'don't give Zainabou THE MONEY.' } & \end{array}$

In line with the account provided for the OV order in section (3), we conceive the alternations above in terms of drawing distinction between objects in emphasis. An account in this regard finds support in Malchukov et al (2010). The fact of imperative as shown in (20-22) is another convincing evidence that supports our claim for a normal VO order in Zarma.

The behaviour of imperative in its negative form is similar to the one we have witnessed above in what we regard as simple/normal double object construction where the verb does not permit the occurrence of the two DP objects together either to its left or right. This is shown in the following examples.

$\begin{array}{lllll}\text { A } & \text { *Màsí } & \text { nòòrú } & \text { Zainabou } & \text { nó } \\ & \text { IMP:NEG } & \text { money } & \text { Zainabou } & \text { give } \\ \text { B } & * \text { Màsí } & \text { Zainabou } & \text { nòòrú } & \text { nó } \\ & \text { IMP:NEG } & \text { Zainabou } & \text { money } & \text { give } \\ \text { C } & * \text { Màsí } & \text { nó } & \text { nòòrú } & \text { Zainabou } \\ & \text { IMP:NEG } & \text { give } & \text { Money } & \text { Zainabou } \\ \text { D } & * \text { Màsí } & \text { nó } & \text { Zainabou } & \text { nòòrú } \\ & \text { IMP:NEG } & \text { give } & \text { Zainabou } & \text { money }\end{array}$

Examples $(23 \mathrm{a}, \mathrm{b})$ indicate that Zarma is not a typical SOV language unlike Batonu (Sanusi 2001). Preverbal position takes an animate object that is definite or an inanimate object that is emphasized. In contrast, it is not allowed for the two objects to follow the verb since the recipient at least must be animate and definite. This explains why examples (23c, d) are ill-formed.

On the form of imperative in Zarma, it is generally accepted that the covert subject of an imperative sentence is the second person singular/plural pronoun (in some languages). The same can naturally be said of the examples we have so far given where $n i$ ' you' is the understood subject. The position of this paper is that, the morpheme màsi which we have interpreted as 
'don't' does not combine in its sense the second person pronoun (singular/plural) with the negative marker in Zarma because $n i$ 'you' which is the invariant form for both singular and plural is not realised on the morpheme.

\subsection{Pronoun and Double Object Constructions}

In sections (4.0 and 4.1), two types of DOCs - simple and imperative were identified and discussed. Each of the two types displays different behaviour in terms of the position of the two internal objects relative to the verb. In the examples we have earlier, the two internal arguments of the verb are DPs with noun complements. However, whenever the recipient in particular, is an understood pronominal item, a different twist is necessarily introduced. It is imperative to mention that personal pronouns in Zarma do not at all inflect for case.

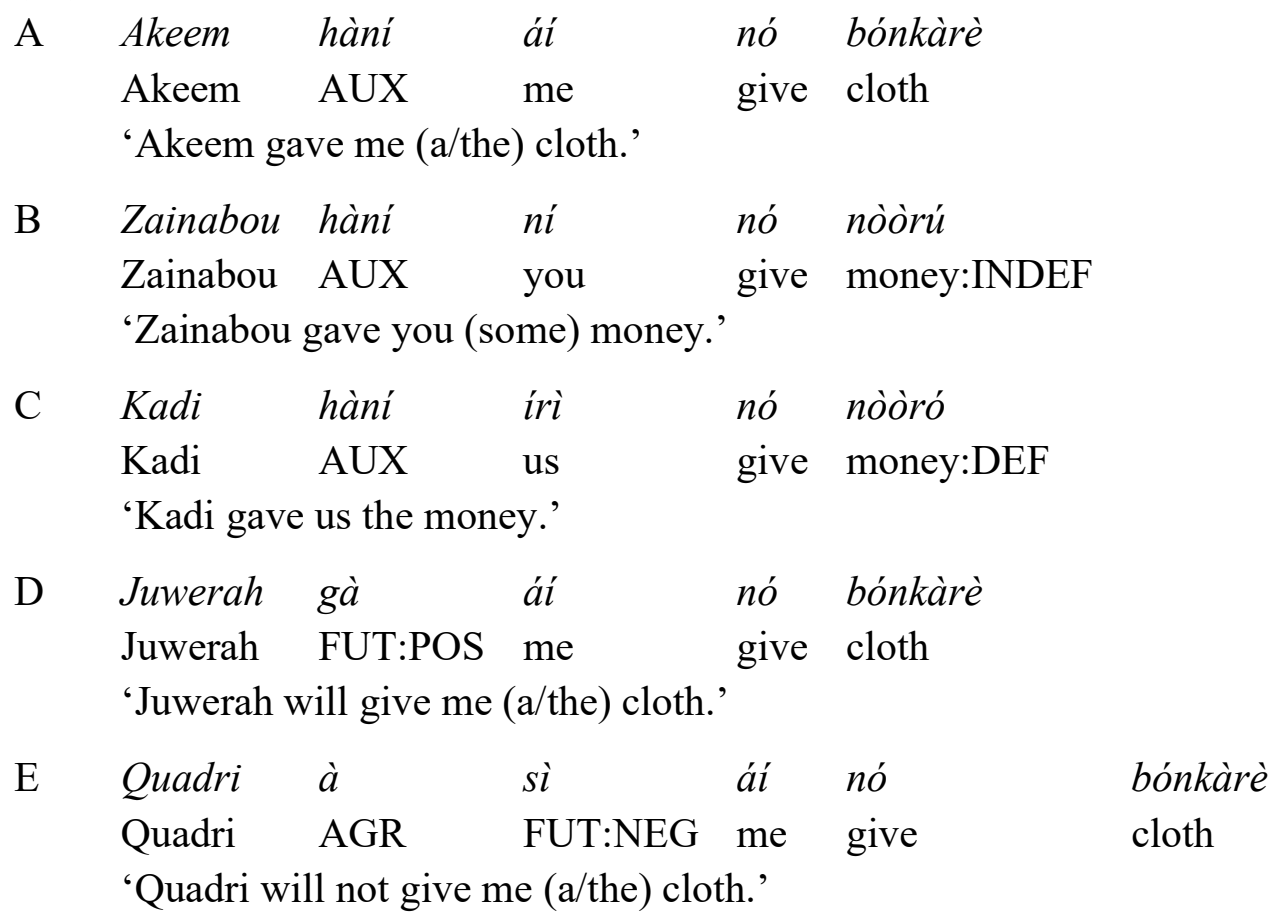

In each of the examples in (24), the recipient consistently occurs before the main verb while the theme follows the verb; any attempt to reorder the objects results in ungrammatical/illicit expression as we have in (25a) below.

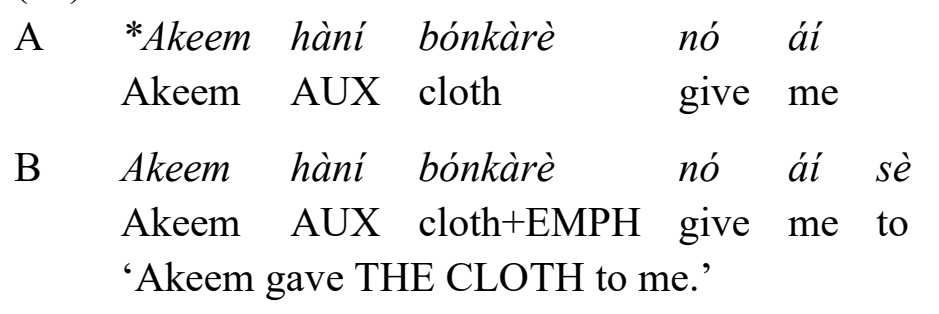

C Quadri à sì bónkàrè nó ái sè

Quadri AGR FUT:NEG cloth+EMPH give me to

'Quadri will not give THE CLOTH to me.' 
The structure in (25a) fails to converge because the pronominal recipient does not occur before the main verb and is also not flagged by a postposition. The example sentences in $(25 \mathrm{~b}, \mathrm{c})$ are well-formed because the recipients are flagged by sè 'to', a postposition. It should be emphasized that $(25 \mathrm{~b}, \mathrm{c})$ are not examples of DOCs but instances of postpositional ditransitive. Anyway, the behaviour of pronouns in DOCs appears to be consistent if we consider their syntactic property in imperative constructions as in (26, 27 and 28).

A Aí nó nò̀rú

me give money:INDEF

'give me money.'

B Írì nó nòòrú

us give money:INDEF

'give us money.'

(27)
A Màsí irì nó nòòrú
IMP:NEG us give money:INDEF
'don't give us money.'
B Màsí i nó nò̀rú
IMP:NEG them give money:INDEF
'don't give them money.'

(28)
A Nó Kadi nòòrú
give Kadi money:INDEF
'give Kadi some money.'
B $\grave{A}$ nó nò̀ó
her give money:DEF
'give her the money.'
C Nó à money:INDEF
give her money
'give her money.'
$\mathrm{D} * \grave{A} \quad n o ́ \quad \grave{a}$
she/he/it give him/her/it

It seems from (28) that the introduction of $\grave{a}$ 'she' in (b) into the numeration which we assume derives its interpretation from Kadi through pronominalization in (a) causes a shift in the position of the recipient before spell-out. The example in (d) fails to converge probably on semantic grounds since $a ̀$ glossed as she/he/it (third person singular) could be +human or -human, feminine, masculine or neuter. Thus, the presence of the two identical pronominal items creates a 
problem of identity of reference. Another reason may be that Zarma double object constructions with pronominal themes are not possible.

The pronominal recipient precedence in Zarma is not at all illustrative because it does not show an alternation in case marking, like full DPs (22). One possibility is to see the phenomenon as a case of cliticization, (cf. Radford (1997a, b); Saah/Eze (1997); Dimmendaal (2010)). In this regard, the verb attracts the pronominal item, here considered as a proclitic to itself. However, no empirical reason will permit us to adopt this proposal: Radford's (1997b) consideration of clitics as products of adjacent constituents merger does not seem to hold for Zarma data because pronominal elements do not merge with the verbs with which they are considered to be adjacent. One way of going around the problem is to suggest that Zarma shows different positional possibilities for nominal versus pronominal arguments. In this case, pronominal recipients appear to be animate and more definite than nominal themes that are inanimate and generally indefinite. This consideration as it applies to nominal recipients predicts that pronominal arguments precede nominal ones. It is likely to be the case that pronominal recipients precede the themes to check their definite/emphatic feature. This situation is not an isolated one. Carnie (2007: 380) shows that a related alternation is possible in English. In his words, with full NPs, the direct object of a complex verb like blow up can either precede or follow the particle up (29a and b), but with pronouns the particle must come after the pronoun $(29 \mathrm{c})$. It is unacceptable for the pronoun to come after the complex verb (29d):
A I blew up the building.
B I blew the building up.
C I blew it up.
D *I blew up it.

\subsection{Asymmetric C-command and Double Object Constructions}

The notion of C-command relation at its first mention would seem incapable of accounting for the alternations found in Zarma double object constructions. Collins/Thrainsson (1996) and Carnie (2007) among others, following Barss/Lasnik (1986) and Larson (1988) uphold the idea that a clear asymmetry exists between the two internal DPs of a double object construction. For instance, the recipient is said to asymmetrically $\mathrm{C}$-command the theme but not vice-versa. This is shown in (30).

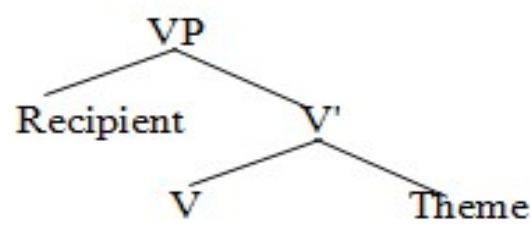

Zarma tolerates the structure in (30) when the recipient object is a pronominal or an animate nominal that is definite. However, it is definitely not the only order allowed. When the two DPs are nominal and the theme is emphasized, the theme occurs to the left side of the verb. Based on this parameter, we can have (30) above and (31) below. 
(31)

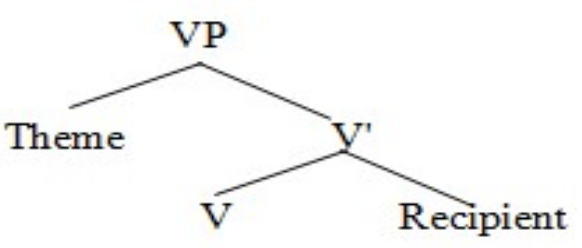

The implication of (30 and 31) is that there are two possibilities in terms of expressing asymmetric C-command relation between the recipient object and the theme object. The matter relating to $\mathrm{C}$-command as contained in the popular literature also bears direct relationship with reflexive which must be C-commanded by its antecedent. This is illustrated with the examples in (32).

\begin{tabular}{|c|c|c|c|c|c|c|}
\hline A & $\begin{array}{l}A i \\
\mathrm{I}\end{array}$ & $\begin{array}{l}n a ̀ \\
\text { PERF:POS }\end{array}$ & $\begin{array}{l}a ́ i \\
\text { my }\end{array}$ & $\begin{array}{l}\text { bò̀n } \\
\text { self }\end{array}$ & $\begin{array}{l}\text { nó } \\
\text { give }\end{array}$ & $\begin{array}{l}\text { nòòrú } \\
\text { money:INDEF }\end{array}$ \\
\hline & 'I gave 1 & yself money. & & & & \\
\hline & Akeem & $n \grave{a}$ & ǹgá & bò̀n & nó & nòòrú \\
\hline & Akeem & PERF:POS & him & self & give & money:INDEF \\
\hline
\end{tabular}

Larson (1988: 336), following Barss / Lasnik (1986) posits that double object structures show an asymmetry with respect to the licensing of anaphors. This may seem to be the case because the reflexives -ái bò̀n 'myself' and ǹgá bò̀n 'himself' are C-commanded by their respective antecedents - $a \dot{a} i$ 'I' and Akeem. However, it sometimes looks like the kind of anaphor-antecedent relation of the type found in (32) does not exist between the two objects - recipient and theme. This seems to be the case with example (20a) repeated here as (33).

$$
\begin{aligned}
& \text { Nó Zainabou nòòru } \\
& \text { give Zainabou money:INDEF } \\
& \text { 'give Zainabou money.' }
\end{aligned}
$$

At spell-out, the sentence above seems to show that the two internal arguments of the verb, nó 'give' mutually or symmetrically C-commands each other. This idea is captured in the structure at (34) taken from Oehrle (1976); it represents one of the early hypotheses about the structure of DOCs.

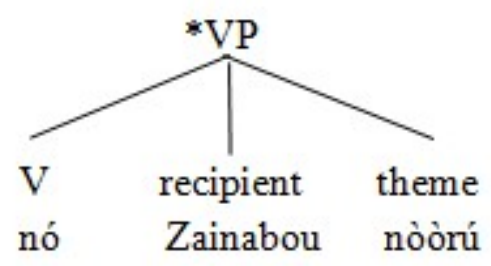

If the structure in (34) is anything to go by, then it may be the case that the criterion of asymmetry between the two DPs of a ditransitive verb does not apply cross linguistically so that it 
should be possible for the two DPs to switch and occur in either position. This is however not the fact of Zarma because the corresponding theme-recipient order in (35) is not well-formed.

$$
\begin{array}{ll}
{ }^{*} \text { nó nò̀rú Zainabou } \\
\text { give money }
\end{array}
$$

The relevance of asymmetric C-command as predicted by the structure of the sentence in (35) shows that the two DPs i.e. recipient and theme in (34) must be in a configuration of the type in (36).

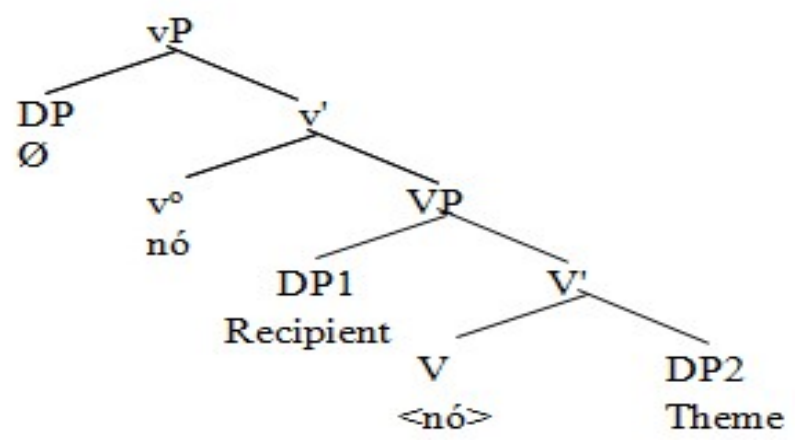

The configuration in (36), following (34 and 35) shows that recipient object C-commands the theme object but not vice-versa. The potency of the foregoing analysis is handled by the SplitVP hypothesis also known as the VP-shell or Light-verb popularized by Chomsky (1995). We adopt this hypothesis to treat the double object construction that we focus in this article in the next section.

\subsection{VP-Shells and Double Object Constructions}

For emphasis sake, the type of DOCs being examined involves a grammatical organization in which the recipient is treated exactly the same as the patient of a typical transitive verb. The third argument of the verb although behaves like complement where it may not be immediately adjacent to the verb as in the case of normal imperative double object (37) or it may be at equidistant relations with the verb in simple double object constructions (38).

$$
\begin{aligned}
& \text { Nó Zainabou nò̀rú } \\
& \text { give Zainabou money } \\
& \text { 'give Zainabou money.' }
\end{aligned}
$$

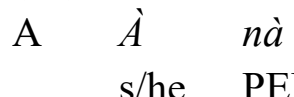
PÈ̀
Akeem
nó
mótò
'S/he has given Akeem a/the motorcar.' 


$$
\begin{aligned}
& \mathrm{B} \quad \grave{A} \text { nà mótò nó Akeem } \\
& \mathrm{s} / \text { he PERF:POS motor give Akeem } \\
& \text { 'S/he gave/has given Akeem a/the MOTOR CAR.' }
\end{aligned}
$$

The constructions of the type in (37 and 38) suggest that the verb nó 'give' allows two complements contra the prediction of X-bar theory; thus, placing the second argument becomes difficult. However, within the fold of the framework which we have adopted in this study, it is claimed that verbs that assign agentive theta role consist of two parts, namely; a verbal root and what is known as a light verb. Therefore, following Larson (1988, 1990), Hale/Keyser (1991, 1993, 1994) and Chomsky (1995), we assume that all the examples in (37 and 38) are complex double-VP structures having an outer VP shell with an inner VP core embedded within it as illustrated in the structure in (39).

\section{[VP [external argument] [V' V [VP [THEME] [V' Verb [RECIPIENT]]]]]}

What we have in (39) does not appear to capture the whole fact of Zarma. In (37) RECIPIENTTHEME order is fixed, whereas in (38), either of the THEME or RECIPIENT can occur before a shell that is headed by a morphologically filled or contentive verb. Each of these facts requires a separate explanation within the chosen framework.

In an attempt to explain the derivation of the expression in (37) we propose that the V nó 'give' is merged with nòrú 'money' to form the V-bar nó nòrú 'give money', which in turn merges with the DP-Zainabou to form a VP which also merges with an abstract causative light verb $\varnothing$ to produce another v-bar. The resulting v-bar structure is then merged with the null subject $\varnothing$ to form a complex vP as shown in (40).

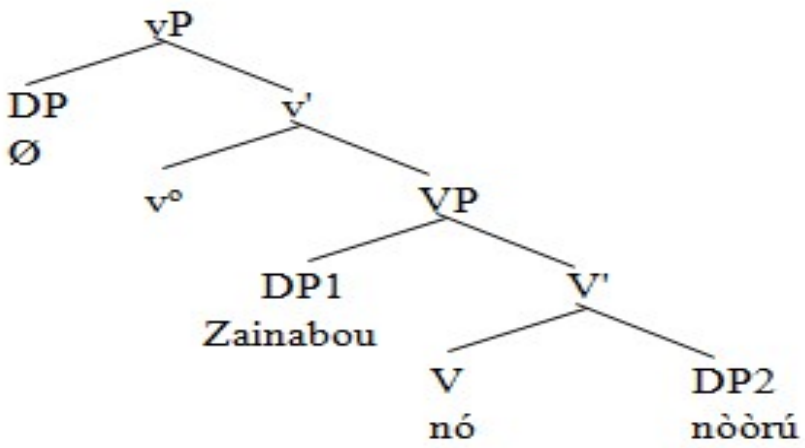

What we have in (40) is not the correct surface order. Thus, we propose that nó 'give' is motivated to move because the light verb or the upper verbal shell has a strong V-feature and this process is followed by the movement of the null-subject to [Spec-TP], as indicated in (41). 
(41)

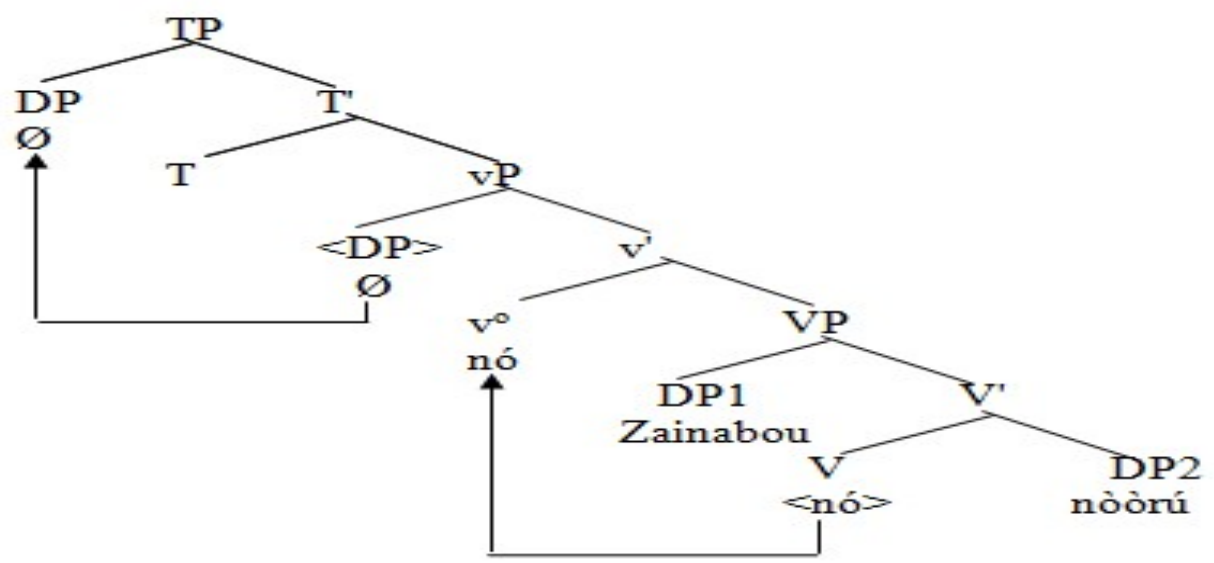

The structure in (41) represents the unmarked or normal order where the recipient being animate and definite precedes the theme. It is possible to also have a marked or deviant order when the THEME precedes the RECIPIENT because it is emphasized. In this case, the THEME is raised to the specifier position of a functional head; call it an Emphatic Phrase, to check its feature. The analysis is presented in (42).

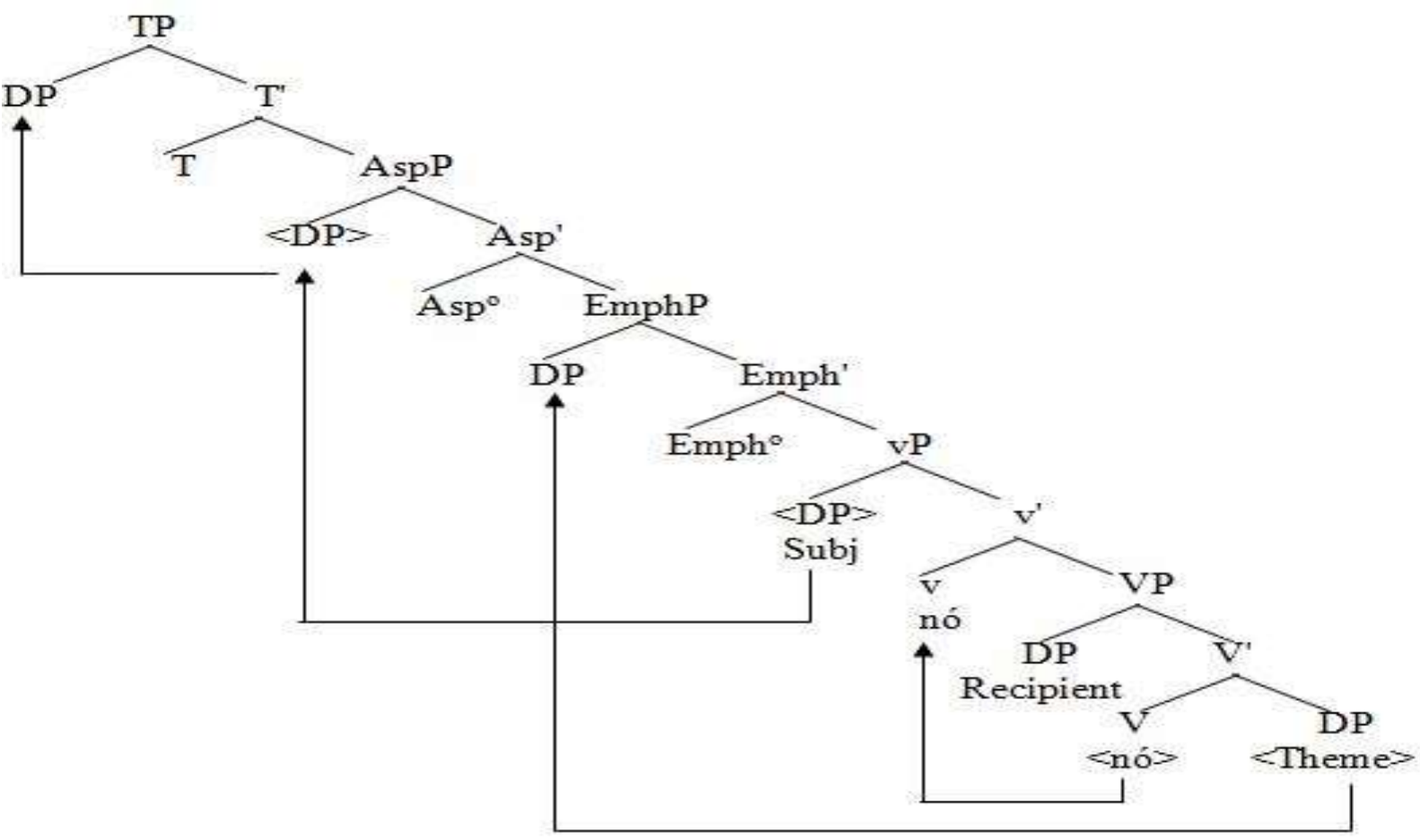

(42) showing the order of theme and recipient

The structure in (42) differs from (41) only with respect to the order of THEME and RECIPIENT. There is a shift in the position of the theme because it is emphasized. This account is consistent with the analysis provided for the alternations between $\mathrm{VO}$ and $\mathrm{OV}$ orders in monotransitive constructions. In (42), the lower V has to move to the upper vP-shell where the external argument that originates at the Spec of the upper vP-shell is $\theta$-marked. The raising of the contentive verb in (42) is in strict compliance with the Head Movement Constraint which says that "a head category can only move to the head position immediately preceding it." 
The analysis of double object constructions along the lines of the VP-shells appears to be intuitively satisfying; however, one fact that seems not to have received any direct attention is how the two internal arguments (object DPs- recipient and theme) check their case. In this connection therefore, an attempt will be made to analyze the situation in the section that follows.

\subsection{Case in Double Object Constructions}

The standard assumption within the minimalist framework is that Nominative Case is checked in Spec-TP under Spec-head relation while Accusative Case is checked by small v, the same head that assigns the Agent theta-role (cf. Chomsky 1995; Markman 2010). This claim nicely accounts for case only in mono-transitive constructions. In the patterns of double object constructions found in Zarma, it is not quite simple to explain the syntactic relations between the verb and its Recipient and Theme objects. This fact explains the convergence of the expressions in (43).

\begin{tabular}{|c|c|c|c|c|c|}
\hline A & $\begin{array}{l}\grave{A} \\
\text { s/he }\end{array}$ & $\begin{array}{l}n a ̀ \\
\text { PERF:POS }\end{array}$ & $\begin{array}{l}a ́ i \\
\text { me }\end{array}$ & $\begin{array}{l}\text { nó } \\
\text { give }\end{array}$ & $\begin{array}{l}\text { bónkàrè } \\
\text { cloth:INDEF }\end{array}$ \\
\hline & 'S/he gave & has given me & a cloth.' & & \\
\hline & $\begin{array}{l}\text { Zainabou } \\
\text { Zainabou }\end{array}$ & $\begin{array}{l}n \grave{a} \\
\text { PERF:POS }\end{array}$ & $\begin{array}{l}\text { Akeem } \\
\text { Akeem }\end{array}$ & $\begin{array}{l}\text { nó } \\
\text { give }\end{array}$ & $\begin{array}{l}\text { mótò } \\
\text { motor:INDEF }\end{array}$ \\
\hline & 'Zainabou & gave/has give & Akeem a moto & car.' & \\
\hline & $\begin{array}{l}\grave{A} \\
\mathrm{~s} / \mathrm{he}\end{array}$ & $\begin{array}{l}n a ̀ \\
\text { PERF:POS }\end{array}$ & $\begin{array}{l}\text { mótò } \\
\text { motor+EMPH }\end{array}$ & $\begin{array}{l}\text { nó } \\
\text { give }\end{array}$ & $\begin{array}{l}\text { Akeem } \\
\text { Akeem }\end{array}$ \\
\hline
\end{tabular}

The property of DOCs observed in (43) will initially appear to fall short of the assumption by (Speas 1990 and Harley 2002) that the recipient argument of a double object verb is generated in [Spec, VP] and that the theme argument is generated as the complement of V. The point here directly relates to the alternations in the position of the two objects. However, it is still safe to say that the property of DOCs in the examples in (43) seem to parallel the structure of DOCs which Speas and Harley (ibid.) analysed. Following from the prediction that recipient objects canonically precede the themes for being animate and definite, Zarma corpus (43a, b) neatly allies to Speas and Harley's proposal. In line with our earlier proposal, the movement of the theme object in (43c) is not for case checking but a means to license its emphatic feature.

The schema in (42) nicely takes care of the issue of case in double object constructions. On the premise that none of the objects is flagged, we predict that Zarma does not forbid two accusatives in the same clause. The recipient argument checks its accusative case in Spec-VP while the theme argument takes its own from the complement of $\mathrm{V}$. We consider our proposal here as nice; it is in consonance with the LCA in that the universal order of Specifier-Head-Complement is maintained. Besides, the Spec-Head checking relationship proposed by the minimalist framework is sustained. Another advantage is that, the functional projection approach (i. e. special functional projection-emphatic phrase) which we adopt provides simplistic account for the theme object shift possibility. It equally satisfies the locality conditions proposed by Rizzi (1990) and Chomsky (1993). Hornstein et al (2005) posit that minimality takes features rather 
than positions into consideration and that, the properties of a given position are fundamentally derived from the features it has. It is the position of this paper that all the movements shown in our analyses are feature induced.

\section{Conclusion}

In this paper, we have tried to explain the alternations found in the position of verb and its internal argument in Zarma monotransitive constructions. Using three different diagnostics; auxiliated $\mathrm{OV}$, definite marking OV and contrastive emphasis OV, the paper argues that Zarma is canonically SVO language. It concludes that the most intuitively satisfying account for SOV order in the language is the discourse status of the object i.e. when it is emphasized. This tendency forces the object that originates as complement of the verb to raise to the specifier position of a special functional projection to check its emphatic feature. The inconsistency in the order of recipient and theme in double object constructions where the recipient is not flagged by a postposition is analysed as effects between orders and semantic interpretations. The paper categorizes double object constructions into two: simple and imperative. On the basis of the categorizations, the paper argues that recipient-theme order is the unmarked in the language because the recipient whether nominal or pronominal is more animate and definite than the theme. The alternative order of theme-recipient is the marked in the language. In this case, the theme which is both inanimate and indefinite climbs to the specifier position of the emphatic phrase where its emphatic feature is checked. Moreover, the study clearly shows that asymmetric c-command relations always hold between the recipient and theme objects. Since neither of the two internal arguments of double object constructions is flagged, we predict that Zarma does not forbid two accusatives in the same clause.

$\begin{array}{llll}\text { Abbreviations } & & \\ \text { AGR } & \text { agreement marker } & \text { NP } & \text { noun phrase } \\ \text { ASP } & \text { aspect } & \text { Obj } & \text { object } \\ \text { AspP } & \text { aspect phrase } & \text { PERF } & \text { perfective aspect } \\ \text { AUX } & \text { auxiliaries } & \text { POS } & \text { positive } \\ \text { CONT } & \text { continuous aspect } & \text { PRES } & \text { present tense } \\ \text { D } & \text { determiner } & \text { PROG } & \text { progressive aspect } \\ \text { DEF } & \text { definite } & \text { SOV } & \text { subject object verb } \\ \text { DO } & \text { direct object } & \text { Spec } & \text { specifier } \\ \text { DOC } & \text { double object construction } & \text { Subj } & \text { subject } \\ \text { DP } & \text { determiner phrase } & \text { SVO } & \text { subject verb object } \\ \text { EMPH } & \text { emphasis } & \text { T } & \text { tense } \\ \text { FUT } & \text { future } & \text { TP } & \text { tense phrase } \\ \text { IMP } & \text { imperative } & \mathrm{V} & \text { verb } \\ \text { INDEF } & \text { indefinite } & \mathrm{VP} & \text { verb phrase }\end{array}$




$\begin{array}{llll}\text { IO } & \text { indirect object } & \varnothing & \text { phonetically zero/nul } \\ \text { LCA } & \text { linear correspondence axiom } & \theta & \text { theta } \\ \text { MP } & \text { minimalist program } & * & \text { ungrammatical expression } \\ \text { NEG } & \text { negative marker/negation } & & \end{array}$

\section{References}

Aboh, Enoch (2004a): The Morphosyntax of Complement-Head Sequences: Clause Structure and Word Order Patterns in Kwa. New York: Oxford University Press.

Aboh, Enoch (2004b): “Topic and Focus within D". Linguistics in the Netherlands 21: 1-12.

Baker, Mark (1988): Incorporation: A Theory of Grammatical Function Changing. Chicago: University of Chicago Press.

Barss, Andrew/Lasnik, Howard (1986): “A Note on Anaphors and Double Objects". Linguistic Inquiry 17: 347-354.

Borsley, Robert (1991): Syntactic Theory: A Unified Approach. London: Edward Arnold.

Carnie, Andrew (2007): Syntax: A Generative Introduction. $2^{\text {nd }}$ ed. Malden/Oxford: Blackwell. Cheng, Lisa/Rint Sybesma (1999): "Bare and Not-So-Bare Nouns and the Structure of NP". Linguistic Inquiry 30: 509-542.

Chomsky, Noam (1993): “A Minimalist Program for Linguistic Theory”. In: Hale, Kenneth/ Keyser, Samuel (eds.): The View from Building 20: Essays in Linguistics in Honor of Sylvain Bromberger. Cambridge, MIT Press: 1-52.

Chomsky, Noam (1995): The Minimalist Program. Cambridge: MIT Press.

Chomsky, Noam (2000): “Minimalist Inquiries: The Framework”. In: Martin, Roger, Michaels, David/Uriagereka, Juan (eds.): Step by Step: Essays on Minimalist Syntax in Honor of Howard Lasnik, Cambridge, Massachusetts/London, England, MIT Press: 89-155.

Collins, Chris/Thrainsson, Hoskuldur (1996): "VP Internal Structure and Object Shift in Icelandic”. Linguistic Inquiry 27: 391-444.

Cormack, Annabel/Smith, Neil (1994): "Serial Verbs". University College London Working Papers in Linguistics 6: 63-88.

Creissels, Denis et al. (2008): “Africa as a Morphosyntactic Area". In: Heine, Bernd/Nurse, Derek (eds.): A Linguistic Geography of Africa. UK, Cambridge University Press: 86-150.

Dimmendaal, Gerrit (2010): "Ditransitive Constructions in Tima". In: Malchukov, Andrej, Martin, Haspelmath/Bernard, Comrie (eds.): Studies in Ditransitive Constructions: A Comparative Handbook. Berlin, Mouton de Gruyter: 204-220.

Hale, Kenneth/Keyser, Samuel (1991): “On the Syntax of Agreement Structure". Lexicon Project. Working papers, MIT, Center for Cognitive Science. Cambridge: MIT Press.

Hale, Kenneth/Keyser, Samuel (eds.) (1993): "On Argument Structure and the Lexical Expression of Syntactic Relations". The View from Building 20: Essays in Linguistics in Honor of Sylvain Bromberger, MIT Press: 53-110.

Hale, Kenneth/Keyser, Samuel (1994): Constraints on Argument Structure. In: Lust, Barbara, Suner, Margarita/Whitman, John (eds.): Heads, Projections and Learnability. New Jersey, Erlbaum/Hillsdale: 53-71.

Harley, Heidi (2002): "Possession and the Double Object Construction". Linguistic Variation Yearbook 2: 29-68. 
Heine, Bernd (1980): "Language Typology and Linguistic Reconstruction: The Niger-Congo Case". Journal of African Languages and Linguistics 2: 95-112.

Hornstein, Norbert, Nunes, Jairo/Grohmann, Kleanthes (2005): Understanding Minimalism. Cambridge: Cambridge University Press.

Jayeola, Waheed (2016): A Movement Approach to Word Order Variations in Zarma, a NiloSaharan Language. Unpublished PhD. Dissertation, University of Ibadan, Ibadan, Nigeria.

Kandybowicz, Jason/Baker Mark (2003): "On Directionality and the Structure of the Verb Phrase: Evidence from Nupe". Syntax 6/2: 115-155.

Kayne, Richard (1994): The Antisymmetry of Syntax. Cambridge: MIT Press.

Koopman, Hilda (1984): The Syntax of Verbs: from Verb Movement Rules in Kru Languages to Universal Grammar. Dordrecht: Foris.

Larson, Richard (1988): “On the Double Object Construction”. Linguistic Inquiry 19/3: 335-391.

Larson, Richard (1990): “Double Objects Revisited: Reply to Jackendoff”. Linguistic Inquiry 21: 589-632.

Madugu, Isaac (1986): “The Nupe a-construction revisited". Journal of West African Languages 16: 99-112.

Malchukov, Andrej, Martin, Haspelmath/Bernard, Comrie (2010): "Ditransitive Constructions: A Typological Overview". In: Malchukov, Andrej, Martin, Haspelmath/Bernard, Comrie (eds.): Studies in Ditransitive Constructions: A Comparative Handbook. Berlin, de Gruyter: $1-64$.

Manfredi, Victor (1997): “Aspectual Licensing and Object Shift”. In: Dechaine, RoseMary/Manfredi, Victor (eds.): Object Positions in Benue-Kwa. The Hague, Holland Academic Graphics: 88-120.

Marantz, Alec (1984): On the Nature of Grammatical Relations. Cambridge, Massachusetts: MIT Press.

Marchese, Lynell (1981): "Exbraciation in the Kru Language family". Paper Presented at The $3^{r d}$ International Conference on Historical Syntax. Boxzkowo, Poland. March 31- April, 3. Published in Historical Syntax. J. Fisiak (ed.). The Hague: Mouton.

Markman, Vita (2010): "Case Theory: A Historical Overview". Language and Linguistics Compass 419: 846-862.

Mous, Maarten (1997): "The Position of the Object in Tunen". In: Dechaine, RoseMary/Manfredi, Victor (eds.): Object Positions in Benue-Kwa. The Hague, Holland Academic Graphics: 123-137.

Oehrle, R. (1976): The Grammatical Status of the English Dative Alternation. Ph.D. Dissertation. MIT: Cambridge, Mass.

Radford, Andrew (1997a): Syntactic Structure and the Structure of English. Cambridge: Cambridge University Press.

Radford, Andrew (1997b): Syntax: A Minimalist Introduction. Cambridge: C U P.

Rizzi, Luigi (1990): Relativized Minimality. Cambridge, Massachusetts: MIT Press.

Saah, Kofi/Eze, Ejike (1997): "Double Objects in Akan and Igbo". In: Dechaine, RoseMary/Manfredi, Victor (eds.): Object Positions in Benue-Kwa. The Hague, Holland Academic Graphics: 139-152. 
Sanusi, Issa (2001): The Syntax of Double Object Constructions in Batonu. Ph.D. Thesis. University of Ilorin, Nigeria.

Speas, Margaret (1990): Phrase Structure in Natural Language. Dordrecht: Kluwer Academic Publishers. 